\title{
Supporting materials for \\ Reversible Protein Adsorption and Bioadhesion on Monolayers Terminated with Mixtures of Oligo(ethylene glycol) and Methyl Groups
}

\author{
S. Balamurugan ${ }^{1}$, Linnea K. Ista ${ }^{1}$, Juchao Yan $^{1}$, Gabriel P. López ${ }^{1}$, J. Fick ${ }^{2}$, M. \\ Himmelhaus ${ }^{2}$, and M. Grunze ${ }^{2 *}$ \\ ${ }^{1}$ Departments of Chemical and Nuclear Engineering and of Chemistry, The University of \\ New Mexico, Albuquerque, NM 87131 and ${ }^{2}$ Angewandte Physikalische Chemie, \\ Universität Heidelberg, Germany
}

\section{Experimental}

1-Undecanethiol, $\left(\mathrm{CH}_{3}\right)$ (98\%) was purchased from Aldrich Chemicals and

$\mathrm{HS}\left(\mathrm{CH}_{2}\right)_{11}\left(\mathrm{CH}_{2} \mathrm{CH}_{2} \mathrm{O}\right)_{6} \mathrm{OH}(\mathrm{OEG})$ was synthesized as described previously ${ }^{1}$ or purchased from Prochimia (Gdansk, Poland). Lysozyme, (EC 3.2.1.17) grade III from chicken egg white, was purchased from Sigma and pyruvate kinase from Bioenzyme Laboratories. Ethanol (Aaper alcohol and chemicals Co.), disodium hydrogen phosphate (J.T. Baker Inc.) and phosphoric acid (E.M. Science) were used as received. Phosphate buffer solution was prepared by titrating $10 \mathrm{mM}$ solution of disodium hydrogen phosphate with dilute phosphoric acid to $\mathrm{pH}$ 7.5. The protein solutions were prepared by dissolving the protein $(1 \mathrm{mg} / \mathrm{mL})$ in cold $\left(4^{\circ} \mathrm{C}\right)$ buffer solution and allowing the solution to warm to room temperature. For ellipsometric measurements the monolayers were prepared on a $200 \mathrm{~nm}$ gold layer on a 25 x 75-mm glass slide as described previously ${ }^{5}$. For bacterial attachment studies SAMs were generated on a $30 \mathrm{~nm}$ gold layer deposited on 24 x 60-mm glass coverslips. For VSFG studies, mixed monolayers of $\mathrm{HS}\left(\mathrm{CH}_{2}\right)_{10}\left(\mathrm{CH}_{2} \mathrm{CH}_{2} \mathrm{O}\right)_{6} \mathrm{OMe}(\mathrm{OME})$ and perdeuterated 1-dodecanethiol $\left(\mathrm{CD}_{3}\right)$ were formed on a $100 \mathrm{~nm}$ gold film evaporated onto a $\mathrm{Si}(100)$ wafer with a $5 \mathrm{~nm}$ Ti interlayer as adhesion promoter.

Mixed OEG/CH $\mathrm{CH}_{3}$ monolayers were prepared using a 95:5 (v/v) ratio of 2.5mM ethanolic solutions of $\mathrm{OEG}$ - and $\mathrm{CH}_{3}$-thiols. ${ }^{2} \mathrm{X}$-ray photoelectron spectroscopy analysis demonstrated that the resultant monolayers had $\chi_{\mathrm{OEG}} \sim 0.5$, as determined by the relative ratios of the $\mathrm{O}_{1 \mathrm{~S}} / \mathrm{Au}_{4 \mathrm{f}}$ peaks between the mixed monolayer and the pure OEG SAM. ${ }^{2}$ Protein adsorption studies were carried out on these SAMs at different temperatures by a previously reported procedure. ${ }^{2}$ Briefly, the protein solution and distilled water were equilibrated at the desired temperature for $1 \mathrm{~h}$. Then the sample was immersed in the protein solution for $2 \mathrm{~h}$, rinsed with the water kept at the experimental temperature, and dried in a stream of dry nitrogen. Thickness measurements were performed on a M-44 multiwavelength ellipsometer, J. A. Woollam Co., Inc.

Cobetia marina (ATCC 25374; basonym Halomonas marina) ${ }^{4}$ was maintained as a slant culture on marine agar after being inoculated from a glycerol stock derived from the rehydration of the original lyophilate from ATCC. Bacteria used in experiments were grown in chemostat under our standard laboratory conditions ${ }^{5}$ at a dilution rate of 0.11 $\mathrm{h}^{-1}$. 
For attachment studies, OEG-, $\mathrm{CH}_{3-}$ or $\mathrm{OEG}-\mathrm{CH}_{3}-\mathrm{SAMs}$ were placed into a parallel flow chamber ${ }^{5}$ and attachment was allowed to proceed for two hours at a flow rate of $0.7 \mathrm{~mL}$ $\mathrm{min}^{-1}$. Attachment occurred either at room temperature, involving no additional modification to the equipment or at $37^{\circ} \mathrm{C}$. For the latter experiments, the flow cell was modified with a polyvinyl heating strip attached to the aluminum top plate. The temperature was monitored with a thermocouple and the samples were considered to be at $37^{\circ} \mathrm{C}$ when the outflow from the flow cell measured this temperature. After 2 hours of attachment, images of at least 10 fields of view within $10 \mathrm{~mm}$ of the horizontal midline of the flow cell were captured and average number of bacteria per square millimeter determined. Images were captured using either a Win TV apparatus or DT3155 frame grabber card and Image Tool processing software.

Attachment and detachment of C. marina was analyzed as described previously for stimuli responsive surfaces and the same attachment and release temperatures used to enable direct comparison between this system and those previously studied. ${ }^{6}$ Briefly, SAMs were submerged in Petri dishes containing $\sim 10^{8}$ C. marina cells $\mathrm{mL}^{-1}$ which had been pre-equilibrated to $37^{\circ} \mathrm{C}$ in a standard cabinet incubator. Attachment was allowed to proceed for two hours, after which time the samples were removed, rinsed in $37^{\circ} \mathrm{C}$ deionized water to remove salt, dried under a stream of nitrogen and the number of cells $\mathrm{mm}^{-2}$ was determined. The samples were then rinsed with $4^{\circ} \mathrm{C}$ artificial seawater (ASW) delivered from a 60 -mL syringe for 10 seconds. The samples were once again rinsed on deionized water and dried before recounting. Control experiments were performed in which the samples were rinsed with $37^{\circ} \mathrm{C}$ ASW.

Determination of Protein Surface Concentrations. The data obtained by ellipsometry indicated that, at $37^{\circ} \mathrm{C}$, lysozyme and pyruvate kinase adsorbed to $\mathrm{OEG} / \mathrm{CH}_{3}$-SAMs with dry ellipsometric thicknesses of $\sim 20$ and $35 \mathrm{~nm}$, respectively; this was comparable to that obtained by Prime and Whitesides for a monolayer of these proteins on a pure $\mathrm{CH}_{3}$ SAM, ${ }^{2}$ Surface plasmon resonance data obtained for the same proteins on pure $\mathrm{CH}_{3}$ SAMs indicated that these thicknesses correspond to surface concentrations of $\sim 170$ and $500 \mathrm{ng} / \mathrm{cm}^{2}$, respectively. ${ }^{7}$ The dry ellipsometric thicknesses of fibrinogen at $37^{\circ} \mathrm{C}(\sim 24$ $\mathrm{nm})$ and room temperature $(\sim 7 \mathrm{~nm})$ are less than that obtained for a monolayer of this protein on a pure $\mathrm{CH}_{3}-\mathrm{SAM}(\sim 60 \mathrm{~nm})$, and correspond to surface concentrations of $\sim 150$ and $\sim 40 \mathrm{ng} / \mathrm{cm}^{2}$, respectively.

\section{Cyclic Attachment and detachment of lysozyme as a function of temperature.}

Figure S-1 shows the adsorption and desorption of lysozyme through four cycles of incubation with protein at $37^{\circ} \mathrm{C}$, followed by rinsing with water and reapplying protein. 


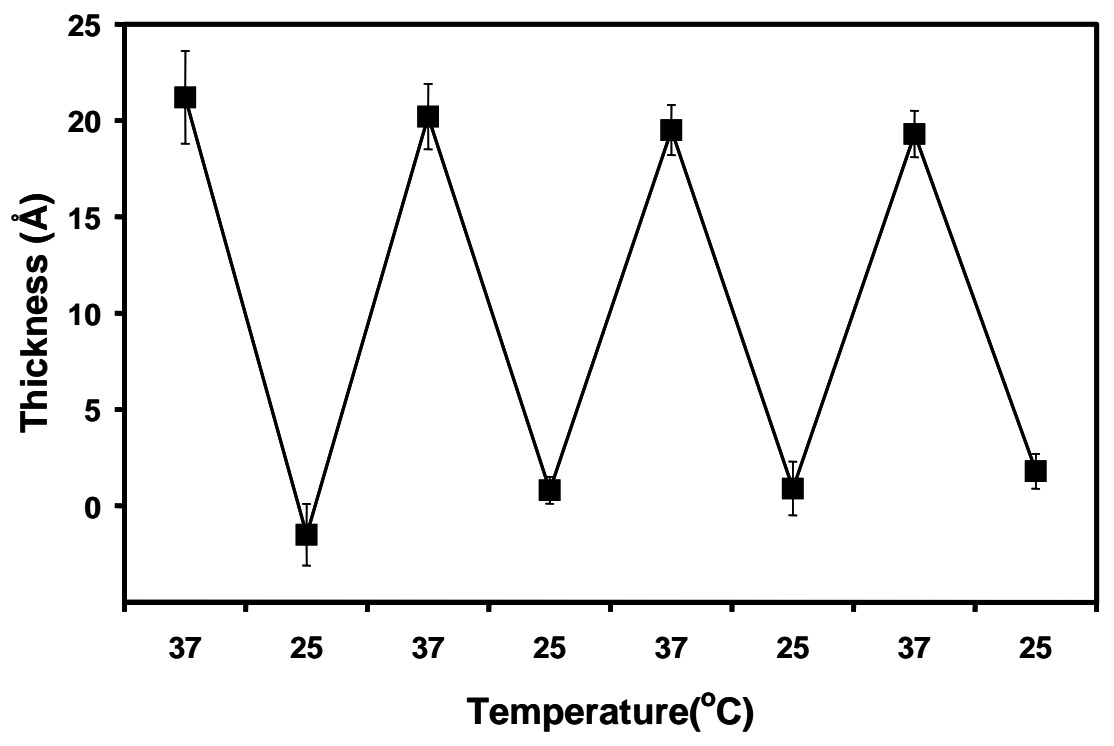

Figure S-1: Attachment and detachment of lysozyme as a function of temperature. A cycle starts with a measurement of protein adsorbed at $37^{\circ} \mathrm{C}$, rinsing at $25^{\circ} \mathrm{C}$ with buffer $\left(1 / 2\right.$ cvcle) and returning to $37^{\circ} \mathrm{C}$.

\section{Contact angles of mixed $\mathrm{OEG} / \mathrm{CH}_{3}-\mathrm{SAMs}$.}

Advancing contact angles were measured for SAMs used in our experiment by two methods. Contact angles of water were measured using a Rame-Hart model 100 contact angle goniometer. Temperature dependent contact angles were measured within a custom built environmental chamber as described previously. ${ }^{3}$ As can be seen in Figure S-2, a sharp contact angle transition from $\sim 41^{\circ}$ to $\sim 52^{\circ}$ occurs between $31^{\circ}$ and $32^{\circ} \mathrm{C}$. This change correlates with an increase in protein adsorption at this temperature (main paper, Figure 1). Contact angle changes were also observed using Wilhelmy Plate analysis using a Kruss Tensionmeter (model 100), with a circulating water bath attached to the fluid ports on the base of the vessel holder. The temperature was measured using a thermocouple inserted into the water being used to take the contact angle. At $25^{\circ} \mathrm{C}, \theta_{\mathrm{AW}}=$ $38+/-2^{\circ}$; at $37^{\circ} \mathrm{C}, \theta_{\mathrm{AW}}=46+/-2^{\circ}$. Both measurements are within statistical agreement with those obtained using the goniometer. Receding contact angles from tensiometer experiments were $37^{\circ}+/-1.4$ at $25^{\circ} \mathrm{C}$ and $43+/-1.2^{\circ}$ at $37^{\circ} \mathrm{C}$, indicating some rearrangement of the OEG chains upon hydration. 


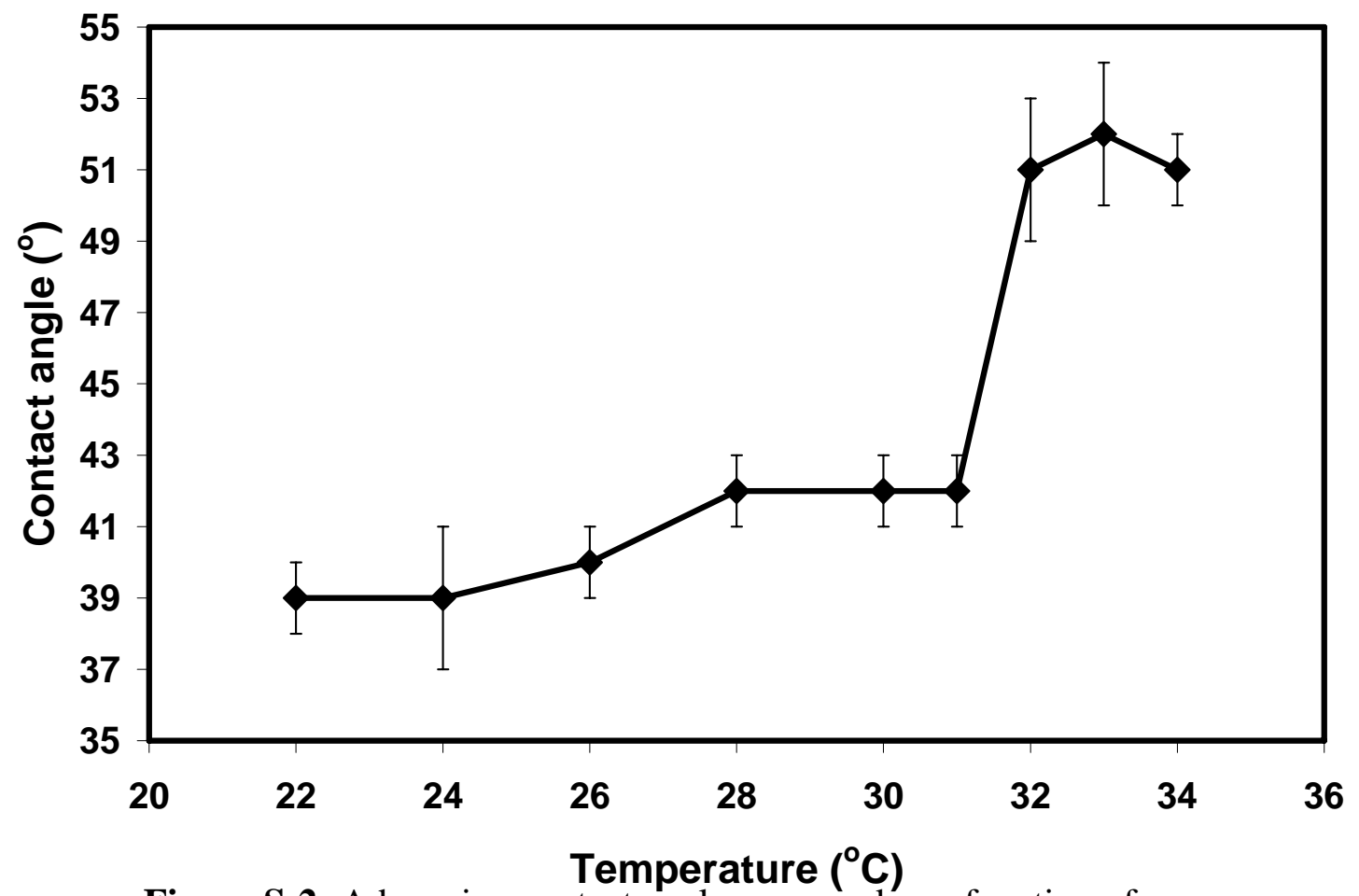

Figure S-2: Advancing contact angle measured as a function of temperature on $\mathrm{OEG} / \mathrm{CH}_{3} \mathrm{SAMs}$.

\section{VSFG study of mixed OME/CD3-SAMs.}

Vibrational sum frequency generation spectra were obtained with a Ti:Sapphire broadband system as described earlier. ${ }^{8}$ In brief, a picosecond NIR beam at $805 \mathrm{~nm}$ is temporally and spatially overlapped with a broadband MIR pulse $\left(\sim 200 \mathrm{~cm}^{-1}\right.$ spectral width) tuned to the range of the $\mathrm{CH}$ stretching vibrations $\left(\sim 2900 \mathrm{~cm}^{-1}\right)$. The resulting SFG signal emerging from the sample surface is spectrally analyzed by means of a monochromator/CCD system. During the measurements, samples were heated by means of a home-built thermal heater equipped with a precision temperature control $\left( \pm 0.2^{\circ} \mathrm{C}\right.$ stability). Samples were covered with a $\mathrm{CaF}_{2}$ window. The gap between the window and the sample surface was adjusted to $\sim 2 \mu \mathrm{m}$ by means of an aluminum spacer to minimize absorption of the MIR beam. For the same reason, deuterated water (99.5\%, SigmaAldrich) was utilized to provide the aqueous environment.

\section{References}

(1) Yan, J. C.; Tender, L. M.; Hampton, P. D.; Lopez, G. P. J. Phys. Chem. B 2001, 105, 8905-8910. 
(2) Prime, K. L.; Whitesides, G. M. J. Amer. Chem. Soc. 1993, 115, 1071410721.

(3) Rao, G. V. R.; Krug, M.E.; Balamurugan, S.; Xu, H. F.; Xu, Q.; Lopez, G. P. Chem. Mater. 2002, 14, 5075-5080.

(4) Arahal, D. R.; Castillo, A. M.; Ludwig, W.; Schleifer, K. H.; Ventosa, A. Syst. Appl. Microbiol. 2002, 25, 207-211.

(5) Ista, L. K.; Callow, M. E.; Finlay, J. A.; Coleman, S. E.; Nolasco, A. C.; Simons, R. H.; Callow, J. A.; Lopez, G. P. Appl. Environ. Microbiol. 2004, 70, 4151-4157.

(6) Ista, L. K.; Pérez-Luna, V. H.; López, G. P. Appl. Environ.Microbiol. 1999, 65, 1603-1609.

(7). Sigal, G.B.; Mrksich, M; and Whiteside, G.M. J. Amer. Chem. Soc. 1998, 120, 3464-3473.

(8) Doyle, A. W.; Fick, J.; Himmelhaus, M.; Eck, W; Graziani, H.;

Prudovsky, I.; Grunze, M; Maciag, T.; Neivandt, D.J. Langmuir 2004, 20, 8961 8965 